\section{Developing wildfire risk probability models for Eucalyptus globulus stands in Portugal}

\author{
Brigite Botequim $^{(1)}$, Jordi Garcia-Gonzalo ${ }^{(1)}$, Susete Marques ${ }^{(1)}$, \\ Alexandra Ricardo ${ }^{(1)}$, José Guilherme Borges ${ }^{(1)}$, Margarida Tomé ${ }^{(1)}$, \\ Maria Manuela Oliveira ${ }^{(2)}$
}

This paper presents a model to predict annual wildfire risk in pure and evenaged eucalypt stands in Portugal. Emphasis was in developing a management-oriented model, i.e., a model that might both: (a) help assess wildfire occurrence probability as a function of readily available forest inventory data; and (b) help predict the effects of management options (e.g., silvicultural treatments) on the risk of fire in eucalypt stands. Data from both the 1995/1998 and the 2005/2006 Portuguese National Forest Inventories as well as wildfire perimeters' data were used for modeling purposes. Specifically, this research considered 1122 inventory plots with approximately 1.2 million trees and 85 wildfire perimeters. The model to predict the probability of wildfire occurrence is a logistic function of measurable and controllable biometric and environmental variables. Results showed that wildfire occurrence probability in a stand increases with the ratio basal area/quadratic mean diameter and with the shrubs biomass load, while it decreases with stand dominant height. They further showed that the probability of wildfire occurrence is higher in stands that are over $1 \mathrm{~km}$ distant from roads. These results are instrumental for assessing the impact of forest management options on wildfire risk levels thus helping forest managers develop plans that may mitigate wildfire impacts.

Keywords: Forest Fires, Forest Management, Eucalyptus globulus Labill, Annual Wildfire Risk Model

\section{Introduction}

Fire is a major disturbance impacting the Mediterranean landscape (Rundel 1998). In recent decades its incidence has increased dramatically in southern Europe (Rego 1992, Moreno 1999, Pereira et al. 2006, Pausas et al. 2008). The Portuguese territory is characterized by a Mediterranean climate and a rugged topography. Moreover, the Portuguese vegetation cover is mostly evergreen and drought resistant. The country is thus prone to vegetation fires. Recent demographic, socio-economic and climatic trends (e.g., Mather \& Pereira 2006, Pereira et al. 2002) have further contributed to the country's vulnerability to wildfires. In Portugal, wildfire

is the most important agent of land cover change (Pereira \& Santos 2003). In fact, in the period extending from 1975 to 2007 the total burned area approximated $3.8 \cdot 10^{6}$ hectares, representing $40 \%$ of the country's area (Marques et al. 2011a).

In Portugal, around $90 \%$ of the total forest land is managed by private landowners (DGRF 2006) and most stands are monospecific or dominated by one species. Eucalypt is the most important forest species in terms of area as it extends over $8.12 \cdot 10^{3}$ ha, corresponding to $26 \%$ of the country's forestland (ICNF 2013). Further, it provides key raw material to the export driven pulp and paper industry (about 5.75 million $\mathrm{m}^{3}$ of pulpwood

(1) Forest Research Centre, School of Agriculture, Departamento de Recursos Naturais, Ambiente e Território, Technical University of Lisbon, tapada da Ajuda, P-1349-017 Lisboa (Portugal); (2) Research Centre in Mathematics and Applications, Colégio Luís Verney, University of Évora, rua Romão Ramanho 59, P-7000-671 Évora (Portugal)

@ Brigite Botequim (bbotequim@isa.utl.pt)

Received: Oct 12, 2012 - Accepted: Mar 18, 2013

Citation: Botequim B, Garcia-Gonzalo J, Marques S, Ricardo A, Borges JG, Tomé M, Oliveira MM, 2013. Developing wildfire risk probability models for Eucalyptus globulus stands in Portugal. iForest 6: 217-227 [online 2013-05-27] URL: http://www.sisef.it/iforest/contents/ ?id=ifor0821-006

Communicated by: Marco Borghetti per year - DGRF 2007). Wildfires constrain the economic viability of eucalypt in commercial forestry and the competitiveness of this industry (Nogueira 1990, Moreira et al. 2001). The development of forest plans that may mitigate wildfire impacts on the profitability of eucalypt management scheduling is thus a key factor to the sustainability of this forestry sub-sector. This prompted the research of models to assess wildfire occurrence probability in eucalypt plantations as a function of variables that may be controlled by forest managers.

The forestry literature has associated the term risk with the probability of occurrence of a natural hazard (González et al. 2006, Jactel et al. 2009, Marques et al. 2012). In this research, we will refer to risk as the probability of a stand to be affected by a wildfire (i.e., probability of burning) if an ignition exists (Marques et al. 2012). Thus, rather than modeling fire ignition probability, the focus of this research is on modeling at stand level the probability of wildfire occurrence at stand level. This is understood as a spatial process related to forest structure as potential fire spread is impacted by fuel presence/composition (Fernandes 2009).

In Portugal, former studies have focused on the characterization of wildfire ignition or of wildfire risk as a function of environmental or socioeconomic variables (Vasconcelos et al. 2001, Pereira \& Santos 2003, Nunes et al. 2005, Carreiras \& Pereira 2006, Catry et al. 2008, 2009, Marques et al. 2011a). It was demonstrated that in general wildfire impacts depend on the forest cover types where they occur (Moreira et al. 2001, Godinho-Ferreira et al. 2005, Nunes et al. 2005, Moreira et al. 2009, Silva et al. 2009, Garcia-Gonzalo et al. 2011a). The characterization of these impacts on eucalypt plantations was addressed recently by Fernandes et al. (2011) and Marques et al. (2011b). Nevertheless, no models to assess the impact of changes in controllable biometric variables on fire occurrence in eucalypt plantations were available in Portugal. This lack of information was a major obstacle to effective eucalypt forest management planning in Portuguese fire-prone regions.

The forest cover type and the understory fuel load have a substantial impact on the probability of wildfire occurrence (Cumming 2001, Ceccato et al. 2002, Castro et al. 2003, Silva et al. 2009, Marques et al. 2011a, Marques et al. 2012) and may be manipulated by management planning to minimize risk. Some authors have analyzed the impact of tree species composition and of fuel reduction activities on wildfire occurrence (Agee \& Skinner 2005, Fernandes et al. 2005, Fernandes \& Rigolot 2007). Fire hazard and spread do depend on both the tree species composition and the understory fuel 


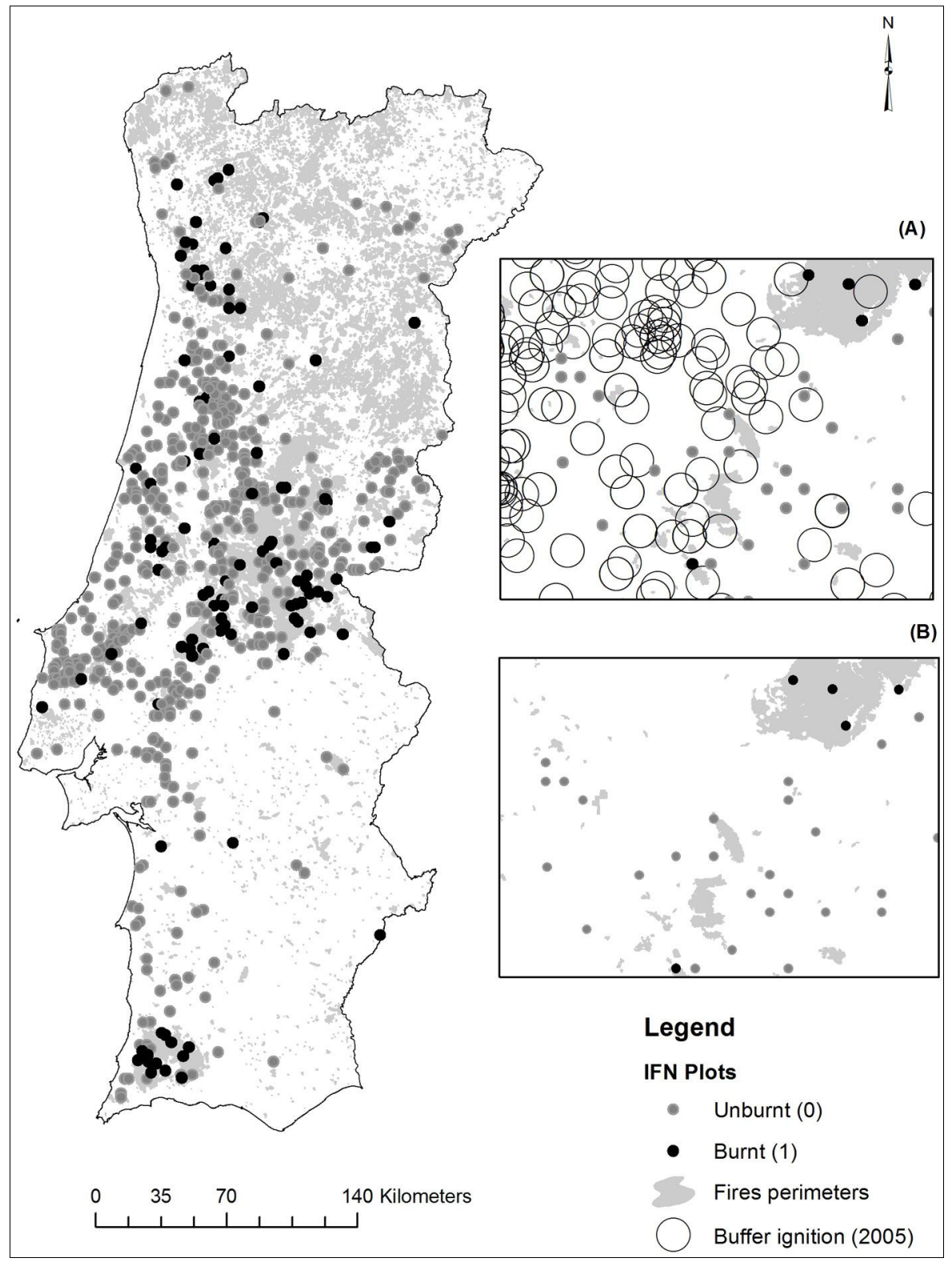

Fig. 1 - Distribution of forest fires occurred in Portugal during the period 1998-2007, overlaid with the pure/even-aged eucalyptus plots. Boxes on the right represent: (A) selection of unburned plots (example for the year 2005) based on their distance from ignition points; (B) a part of the National Forest Inventory plots used in the study.

structure (e.g., Rothermel 1983, Graham et al. 2004, Peterson et al. 2005, Fernandes et al. 2006, Silva et al. 2009). They thus depend too on forest and fuel management regimes (Graham et al. 1999, Omi \& Martinson 2004, Jactel et al. 2009, CrecenteCampo et al. 2009). In fact, the relationship between fuel load, rate of spread, and fire intensity has provided a simple but powerful argument to support fuel reduction in eucalypt forests (McArthur 1962, 1967, Peet 1965). The effectiveness of forest management under wildfire risk depends on the availability of information about the impact of management-controllable variables, i.e., probability in the corresponding forest cover type. Their usefulness has been further demonstrated in the framework of the development of optimal management plans under wildfire risk (González et al. 2008, Garcia-Gonzalo et al. 2011a, Ferreira et al. 2011, Ferreira et al. 2012).

The objective of this research was thus to develop a management-oriented model to predict annual wildfire risk in pure and evenaged eucalypt stands in Portugal, i.e., a model that might both: (a) help assess wildfire occurrence probability as a function of readily available forest inventory data; and (b) help predict the effects of management options (e.g., silvicultural treatments) on the risk of fire in eucalypt stands. After describing the modeling approach, results are discussed to highlight the contribution of this research to address eucalypt wildfire and forest management concerns and help mitigate catastrophic damage to eucalypt plantations.

\section{Materials and methods}

\section{Materials}

\section{Wildfire perimeters and inventory plots}

The assessment of wildfire risk probability in eucalypt stands was based on historical fire information from 1998 to 2007 . The fire data consisted of all perimeters of wildfires larger than 5 hectares. Burned area maps were produced at the Remote Sensing Laboratory of Instituto Superior de Agronomia by semi-automated classification of medium-resolution remote sensing data (i.e., Landsat Multi-Spectral Scanner - MSS, Landsat Thematic Mapper -TM, and Landsat Enhanced $\mathrm{TM}+$ ). In this period, wildfires burned over $1.5 \cdot 10^{5}$ hectares distributed over 12273 perimeters larger than 5 hectares.

This research was further based on data from the $4^{\text {th }}$ and $5^{\text {th }}$ Portuguese National Inventories (NFIs) carried out in two different and discontinuous periods (1995-1998 and 2005-2006, respectively). Each NFI used its own grid to layout the plots. Therefore no permanents plots were available. Additionally, the number of measured plots has not been constant across NFI. In total, 615 and 1351 pure and even-aged eucalypt plots were inventoried out of the 2336 and 12258 total plots measured in the $4^{\text {th }}$ and the $5^{\text {th }}$ NFI, respectively. This research considered plots that were classified by the NFI as productive even-aged pure eucalypt forest and that included the measurement of biometric variables as well as information about the fuel load understory (very young plots where trees are no measured were not included). Thus all plots considered for modeling purposes did include biometric and environmental data relevant for management planning purposes such as tree height, tree dia- 
meter at breast height $(d)$ - for trees holding a $d$ greater or equal to $7.5 \mathrm{~cm} \mathrm{-,} \mathrm{stand} \mathrm{age,}$ stump diameter (e.g., the mean stump diameter of trees that died as a consequence of a wildfire), condition of the tree (dead, alive, cut), number of trees, shrubs species, mean shrubs height, aspect and slope.

An altitude map obtained from the Country's Digital Terrain Model (DTM) with a $30 \mathrm{~m}$ pixel accuracy was overlaid with the NFI plots layers to get the altitude of each plot. The latter were further overlaid with a GIS layer that classifies the territory into two road proximity classes (the threshold being 1 kilometer - Marques et al. 2011a) to classify each plot according to its distance to the closest road. A similar procedure was used to classify each plot according to the population density (number of inhabitants living in each parish - Marques et al. 2011a), precipitation (average of number of days per year with precipitation $\geq 1.0 \mathrm{~mm}$ ) and temperature (yearly average air temperature). The historical weather records used were developed by Tomé et al. (2006), based on the climatological normal of reference (period 1931-1960 in 334 different places in Portugal) from the Atlas do Ambiente.

\section{Analyzing the status of eucalypt plots}

Wildfire perimeters and NFI maps were overlaid using ArcGIS ${ }^{\circledR} 9.2$ to check whether the eucalypt plots were burned or not within sub-periods extending up to six years (19982004) after the first inventory and up to two years (2005-2007) after the second one (data from 2008 were not available). This provided the status (burnt/unburnt) of each eucalypt plot. The definition of these time frames balanced the benefits of having a larger sample size and the costs associated with potential land cover changes in the period ranging from the inventory and the wildfire occurrence. Over the two sub-periods, 109 (59 plots from $4^{\text {th }} \mathrm{NFI}$ and 50 from $5^{\text {th }} \mathrm{NFI}$ ) pure and even-aged eucalypt plots were burned at least one time, while 446 were left unburned (117 plots from $4^{\text {th }}$ NFI and 329 plots from the $5^{\text {th }}$ NFI, respectively - Fig. 1).

\section{Reverse engineering to rebuild the tree characteristics}

The sample size was constrained by the low number of even-aged and pure eucalypt stands and by the fact that most of the $5^{\text {th }}$ NFI plots had been burned before the inventory in 2005. In fact, 47 out of the 50 plots selected by the $5^{\text {th }}$ NFI, burned months before the inventory took place. In order to overcome this problem and take advantage of available inventory data, a reverse engineering methodology (McClure 1968, Bylin 1982, Diéguez-Aranda et al. 2003, GarciaGonzalo et al. 2011b) was used to re-build the forest plot before the wildfire occurrence (Fig. 2). Firstly, these plots were further in- ventoried to get the diameter of stumps from trees that burned and had been harvested. Secondly, this diameter was input to an equation developed by Marques et al. (2011b) to estimate the pre-fire tree diameter at breast height. Thirdly, the latter was input to an equation developed for eucalypt by Tomé et al. (2007) to estimate the tree height (eqn. 1):

$$
h=\frac{d}{\beta_{0}+\beta_{1} d}
$$

where $h$ is the tree height (m), $d$ is the diameter of the breast height $(\mathrm{cm}), \beta_{0}=0.6733$ and $\beta_{1}=0.0130$.

In the case of plots with standing burned trees, pre-fire diameter at breast height was assumed to be unaffected by fire and tree height was estimated by eqn. 1 .

\section{Simulating vegetation growth}

The development of a model to estimate the annual probability of wildfire occurrence as a function of biometric variables required the simulation of vegetation growth. Both a stand-level growth and yield model (Barreiro \& Tomé 2011) and a shrub growth model (Botequim et al. 2009) - previously used by Marques et al. (2012) to estimate understory growth in Portuguese forests - were used to estimate the annual values of biometric variables of each plot in the period ranging from the inventory date to either the fire event date or the date of the next inventory. The simulation thus provided $n$ temporal snapshots of each plot, where $n$ is the number of years of this projection period. For modeling purposes, a dichotomous variable was assigned to each snapshot of each plot. This categorical variable takes the value " 1 " if a wildfire occurred in that year or the value " 0 " if the plot did not burn in that year. The former thus corresponded to the first simulation stopping criteria. If no fire events occurred, projections in the case of $4^{\text {th }}$ NFI plots stopped in year 2004 as another inventory was available for year 2005 , thus meeting the second simulation stopping criteria.

In order to strengthen to snapshot assumption by the simulation, satellite images were processed using IDRISI 3.2 to check whether there had been any harvest and forest cover change both in plots where the eucalypt age was over 9 years at the time of the wildfire event and in plots where the forest growth was projected over more than 6 years (Fig. 2). Specifically, Landsat 5TM images were used to check the cover type in $764^{\text {th }}$ NFI unburned plots in each year in the period from 1998 to the year of wildfire occurrence or to 2004. MOS - Modular Optoelectronic Scanner and SPOT Satellite imagery were used to check the cover type in $1015^{\text {th }}$ NFI unburned plots in each year of the period from 2005 to the year of wildfire occur- rence or to 2007. This check provided a list of 103 plots where no harvests and no cover type changes did occur ( 38 plots from the $4^{\text {th }}$ NFI and 65 from $5^{\text {th }}$ NFI).

\section{Selecting unburned plots: proximity of fire ignition data}

The official database from the Portuguese Forest Service (AFN) that stores the starting coordinates (ignition) of wildfires was used to further select plots to be considered for modeling purposes. For each year, a 2 kilometers buffer around each ignition was created to cover all burned plots in that year. This procedure eliminated from the analysis unburned plots that were not affected by a wildfire because there was no ignition point nearby rather than because of its biometric and environmental characteristics (Fig. 1, Fig. 2). In total, 319 unburned observations (plot yearly simulation snapshots) from 1998 to 2004 and 694 unburned observations (plot yearly simulation snapshots) from 2005 to 2007 were used to fit the model (Tab. 1). Thus the model was fit considering a total of 1122 observations (1 013 unburned observations and 109 burned observations).

\section{Methods}

\section{Annual wildfire occurrence probability model}

The occurrence of wildfire in a stand is a binomial outcome that may be modeled by logistic regression. Actually, this is one of the most popular mathematical modeling approaches to describe the relationships of a set of variables with a dichotomous dependent variable (Hosmer \& Lemeshow 2000). The logistic function in eqn. 2 is mathematically flexible, easy to use, and has a meaningful interpretation (Hosmer \& Lemeshow 2000). The logistic regression model can be presented as (eqn. 2):

$$
Y=\frac{1}{1+e^{-\left(\beta_{0}+\beta_{l} X_{1}+\ldots+\beta_{p} X_{p}\right)}}
$$

where $Y$ is the dependent variable, i.e., the

Tab. 1 - Number of observations recorded as burnt and unburnt areas in the studied period (1998-2007).

\begin{tabular}{ccrr}
\hline Year & Unburnt & Burnt & Total \\
\hline 1998 & 14 & 1 & 15 \\
1999 & 6 & 2 & 8 \\
2000 & 45 & 2 & 47 \\
2001 & 67 & 3 & 70 \\
2002 & 74 & 2 & 76 \\
2003 & 62 & 46 & 108 \\
2004 & 51 & 3 & 54 \\
2005 & 266 & 46 & 312 \\
2006 & 222 & 1 & 223 \\
2007 & 206 & 3 & 209 \\
Total & 1013 & 109 & 1122 \\
\hline
\end{tabular}




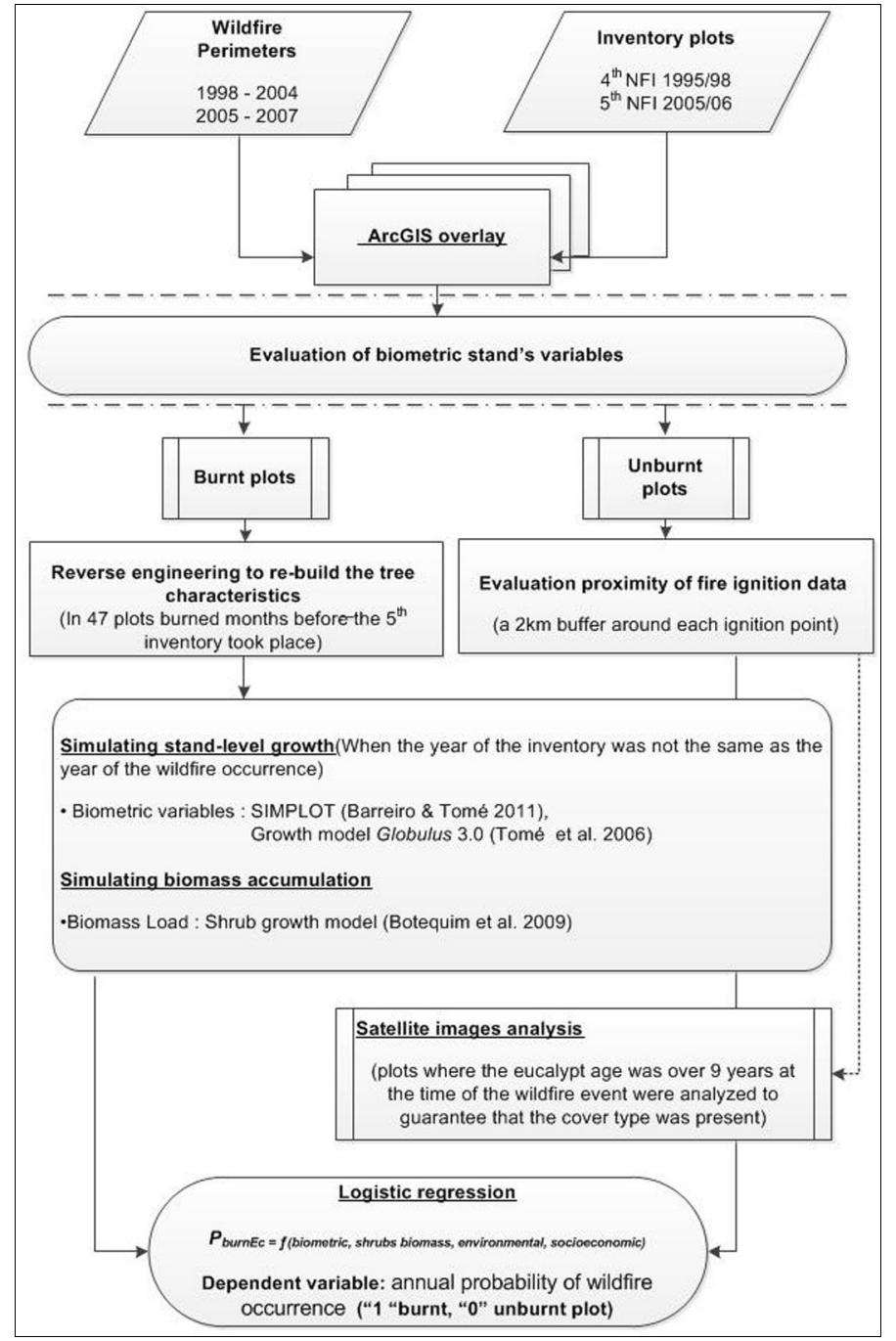

Fig. 2 - Methodology applied to develop an annual wildfire risk probability model for eucalypt stands in Portugal.

Tab. 2 - Statistics for the fitting dataset. (U): Unburnt; (B): Burnt.

\begin{tabular}{|c|c|c|c|c|c|c|c|}
\hline \multirow{2}{*}{ Variables } & \multirow{2}{*}{ Description } & \multicolumn{2}{|c|}{ Min } & \multicolumn{2}{|c|}{ Mean } & \multicolumn{2}{|c|}{ Max } \\
\hline & & $\mathbf{U}$ & B & $\mathbf{U}$ & B & $\mathbf{U}$ & B \\
\hline Age (years) & Stand age & 1 & 2 & 10.09 & 11.42 & 27 & 30 \\
\hline $\begin{array}{l}\text { Altitude } \\
(\mathrm{m})\end{array}$ & Terrain altitude & 15 & 48 & 217.43 & 257.88 & 1015 & 688 \\
\hline $\begin{array}{l}\text { Bshrubs } \\
\left(\mathrm{Mg} \mathrm{ha}^{-1}\right)\end{array}$ & Shrubs biomass load & 0 & 0.44 & 5.81 & 11.3 & 15.2 & 15 \\
\hline $\mathrm{dg}(\mathrm{cm})$ & $\begin{array}{l}\text { Quadratic mean } \\
\text { diameter }\end{array}$ & 0.8 & 2.52 & 12.32 & 13.2 & 31.39 & 23.69 \\
\hline hdom (m) & Stand dominant height & 1.58 & 4.35 & 17.66 & 17.93 & 33.89 & 33.65 \\
\hline $\mathrm{G}\left(\mathrm{m}^{2} \mathrm{ha}^{-1}\right)$ & Stand basal area & 0.1 & 0.09 & 12.5 & 12.09 & 52.64 & 36.16 \\
\hline $\mathrm{G} / \mathrm{dg}$ & Stand structure & 0.01 & 0.01 & 1 & 1.03 & 3.73 & 13.19 \\
\hline $\begin{array}{l}\text { Ntrees } \\
\text { (N/ha) }\end{array}$ & Stand density & 20 & 20 & 1113.88 & 980.44 & 5334 & 5007 \\
\hline $\begin{array}{l}\text { Precipita } \\
\text { (days/year) }\end{array}$ & $\begin{array}{l}\text { Precipitation days in } \\
\text { the area }\end{array}$ & 55.8 & 55.2 & 105.1 & 100.64 & 145 & 145 \\
\hline $\begin{array}{l}\text { Pop } \\
\left(\mathrm{hab} / \mathrm{m}^{2}\right)\end{array}$ & Population per parish & 8.22 & 0.68 & 151.27 & 142.91 & 2325.43 & 1239.6 \\
\hline Slope $\left(^{\circ}\right)$ & Terrain slope & 0 & 0 & 11.5 & 12.47 & 45 & 35 \\
\hline Temp $\left({ }^{\circ} \mathrm{C}\right)$ & $\begin{array}{l}\text { Yearly main } \\
\text { temperature in the area }\end{array}$ & 8.75 & 8.75 & 14.39 & 14.44 & 21.3 & 16.75 \\
\hline
\end{tabular}

Tab. 3 - Statistics for the categorical fitting dataset. (U): Unburnt; (B): Burnt.

\begin{tabular}{llrr}
\hline Variables & \multicolumn{1}{c}{ Description } & U & B \\
\hline Sunny & East (E) & 146 & 13 \\
aspect & Flat (F) & 49 & 3 \\
& North (N) & 148 & 14 \\
& Northeast (NE) & 181 & 25 \\
& Northwest (NW) & 111 & 8 \\
\hline Shady & South (S) & 92 & 18 \\
aspect & Southeast (SE) & 66 & 5 \\
& Southwest (SW) & 96 & 4 \\
& West (W) & 124 & 19 \\
\hline Road & $<1 \mathrm{~km}$ & 464 & 42 \\
Distance & $>1 \mathrm{~km}$ & 549 & 67 \\
\hline
\end{tabular}

annual probability of wildfire occurrence in a pure even-aged eucalypt stand, $x_{1}$ to $x_{\mathrm{p}}$ are independent variables and $\beta_{0}$ to $\beta_{\mathrm{p}}$, are parameters to be estimated.

For modeling purposes, this research considered the plot-level dichotomous categorical variable that takes the value " 1 " if a wildfire did occur (burnt plot) and " 0 " otherwise (unburnt plot). It further considered a large set of explanatory variables including biometric (e.g., stand basal area, age, quadratic mean diameter of trees in the stand), environmental (e.g., altitude, aspect, number of precipitation days) and socioeconomic variables (e.g., distance to roads, population). In total, 14 independent variables, 12 of which are continuous (Tab. 2) and two are categorical (Tab. 3) were considered. In the case of the variable distance to the closest road a dummy variable was created indicating the plot accessibility. This variable was assigned the value " 1 " when the distance from the road network was more than 1 kilometer (Road distance $>1 \mathrm{~km}$ ) and " 0 " if the distance was less than 1 kilometer (Road distance $<1 \mathrm{~km}$ ).

The annual wildfire occurrence probability model was developed using maximum likelihood methods (Monserud \& Sterba 1999) as implemented in the PROC LOGISTIC routine of the SAS 9.1 package (SAS Institute Inc. 2004). The selection of predictors out of the proposed set of explanatory variables was based on the test of the models corresponding to all possible combinations of variables $x_{1}$ to $x_{\mathrm{p}}$ (Freire 2009). Model building further took advantage of an understanding of the process of wildfire occurrence. All predictors had to be logical and significant $\left(\alpha=0.05\right.$, as from Wald $\chi^{2}$ statistics). The presence of collinearity was assessed by adding new variables to the model and observing its impact on the slope coefficients and the estimated standard errors (Hosmer \& Lemeshow 2000). Alternative models were compared using the Akaike Information Criterion (AIC - Burnham \& Anderson 2003, Silva et al. 2009) and further considering the ecological consistency of predictors (i.e., 
signs of coefficients that are biologically reasonable) as well as management relevance (i.e., the model includes variables easy to obtain by a forest inventory). Model goodnessof-fit was assessed using Hosmer-Lemeshow goodness-of-fit statistics.

The validation of the models encompassed the analysis of the functional relations. No specific validation data sets were set aside and later used for that purpose. Two main reasons justify this decision. Firstly, the relatively small number of observations in the dataset used. Secondly, the emphasis of this research was in obtaining the best possible parameter estimates. The authors are aware of the advantages and disadvantages of splitting the data set for model validation purposes (well discussed for instance in Myers 1990 and Kozak \& Kozak 2003). However, they concluded that cross validation by data splitting and double cross validation would provide little, if any, additional information to the evaluation of the regression models.

The Receiver Operating Characteristic (ROC) curve (SAS Institute, Cary, NC) was used to assess the functional relations in the wildfire occurrence model (Shapiro 1999, Hosmer \& Lemeshow 2000). The ROC curve relies on the false/true - positive/negative proportion, where sensitivity is the proportion of wildfire occurrence responses that are correctly predicted and specificity is the proportion of no wildfire occurrence - responses that are also correctly predicted. A model with a ROC curve of 0.5 suggests no discrimination, 0.7-0.8 suggests having an acceptable discrimination, and $0.8-0.9$ provides an excellent discrimination (Hosmer \& Lemeshow 2000). The concordance analysis procedure was further used to support the interpretation of model outcomes (Kleinbaum 1996, Hosmer \& Lemeshow 2000).

The odds ratio was further used to help interpret the role of each independent variable in explaining the probability of wildfire occurrence, as it estimated the net increase in the event probability caused by a unit change in the independent variable (Kleinbaum 1996, Hosmer \& Lemeshow 2000). However, the change in the odds ratio resulting from non-marginal changes in the independent variable is often of greater interest and was further considered. Exponentiation of the parameter estimate for the independent variables in the model by the number "c" yields the odds ratio, where "c" is the increase in the corresponding independent variable.

The logistic model predicts the probability of an occurrence ranging continuously between 0 and 1 . In order to convert an event probability (wildfire risk) to a dichotomous (e.g., burnt/unburnt) data an optimal cut-point must be defined and compared to each estimated probability (Hosmer \& Lemeshow 2000). Different methods have been proposed to select the cut-point/threshold (Monserud \& Sterba 1999, Crecente-Campo et al. 2009). The optimal cut-point value can be defined according to data specificities or risk perception/needs of the users, and sometimes classification between burnt/unburnt stands is not even necessary in forest planning. Although we do not need this cutpoint, we calculated it as an indicative value for users who just want to use the model to predict if a stand may burn or not. For this purpose, three different methods were used to define the cut-point: (1) the value that maximizes the index of concordance and correct classification rate (CCR - e.g., Ryan 1997); (2) the value where the sensitivity curve and the specificity curve cross each other (Hosmer \& Lemeshow 2000); (3) the average observed percentage of event occurrence in the original data (Monserud \& Sterba 1999). In order to select optimal values, tables with classification error rates associated with the different methods were constructed.

\section{Eucalypt coppice stand management scheduling}

The annual wildfire risk model was used to help assess the impact of potential management actions in a typical eucalypt stand. In Portugal, a typical eucalypt prescription encompasses a plantation of about 1250 seedlings $\mathrm{ha}^{-1}$. A full rotation may include up to 2 or 3 coppice cuts, each cut being followed by a stool thinning that may leave an average number of shoots per stool ranging from 1 to 2. Harvest ages typically range from 10 to 12 (Soares \& Tomé 2001). Prescriptions further include several shrub cleanings over a rotation (i.e., 1 to 3 fuel treatments per cycle Duncker et al. 2012).

For demonstration purposes, it was assumore than 1 kilometer from the road network. It was further assumed that the terrain altitude was 217 meters, the slope was $11.5^{\circ}$, med that the eucalypt stand was located at

the mean annual precipitation was $650 \mathrm{~mm}$ and that the understory shrub vegetative community had a re-sprouting ability of $50 \%$. The prescription included a cutting cycle of 10 years, 3 coppice cuts and 1 or more shrub cleanings per cycle. It was also assumed that the stand was within the range of ignition points every year of the planning horizon. Stand and understory growth were estimated using the simulators developed by Barreiro \& Tomé (2011) and Botequim et al. (2009), respectively.

\section{Results}

\section{Annual wildfire occurrence probability} model

The logistic model selected to predict the annual wildfire occurrence in a pure and even-aged eucalypt stand is as follows (eqn. $3)$ :

$$
\begin{gathered}
\text { PburnEC }=\frac{1}{1+e^{-\left(\begin{array}{l}
-5.4005-0.054 \cdot \text { hdom }+0.3166 \cdot G / d g \\
+0.3959 \cdot \text { Bshrubs }+0.5372 \cdot \text { RoadDist }
\end{array}\right)}} \\
\left\{\begin{array}{ll}
\text { RoadDist }=0 & \text { if }(\text { RoadDistance }<1 \mathrm{~km}) \\
\text { RoadDist }=1 & \text { if }(\text { RoadDistance }>1 \mathrm{~km})
\end{array}\right\}
\end{gathered}
$$

where Bshrubs is the total biomass of shrubs $\left(\mathrm{Mg} \mathrm{ha}^{-1}\right), h d o m$ is the stand dominant height (m), $G / d g$ is a predictor combining information about density and tree sizes where $G$ is the basal area $\left(\mathrm{m}^{2} \mathrm{ha}^{-1}\right)$ and $d g$ is the quadratic mean diameter of trees in the stand $(\mathrm{cm})$ and RoadDist is a dummy variable indicating the proximity to the road network. Specifically, if the distance to the network is less than 1 kilometer, RoadDist takes the value " 0 " otherwise it takes the value " 1 ".

According to the model, stands with higher density are in general more prone to burn (Fig. 3). Yet this further depends on the tree sizes. For the same basal area, the value of predictor $G / d g$ decreases with the quadratic mean diameter, thus highlighting that the

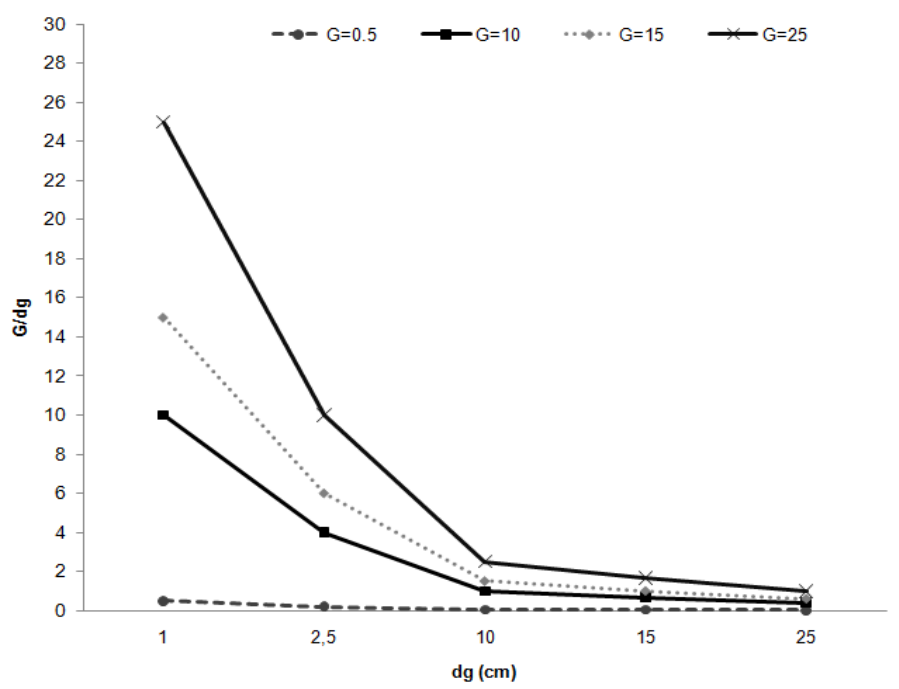

Fig. 3 - Values of the variable $G / d g$ for different combinations of basal area $(G)$ and quadratic mean diameter $(d g)$. 

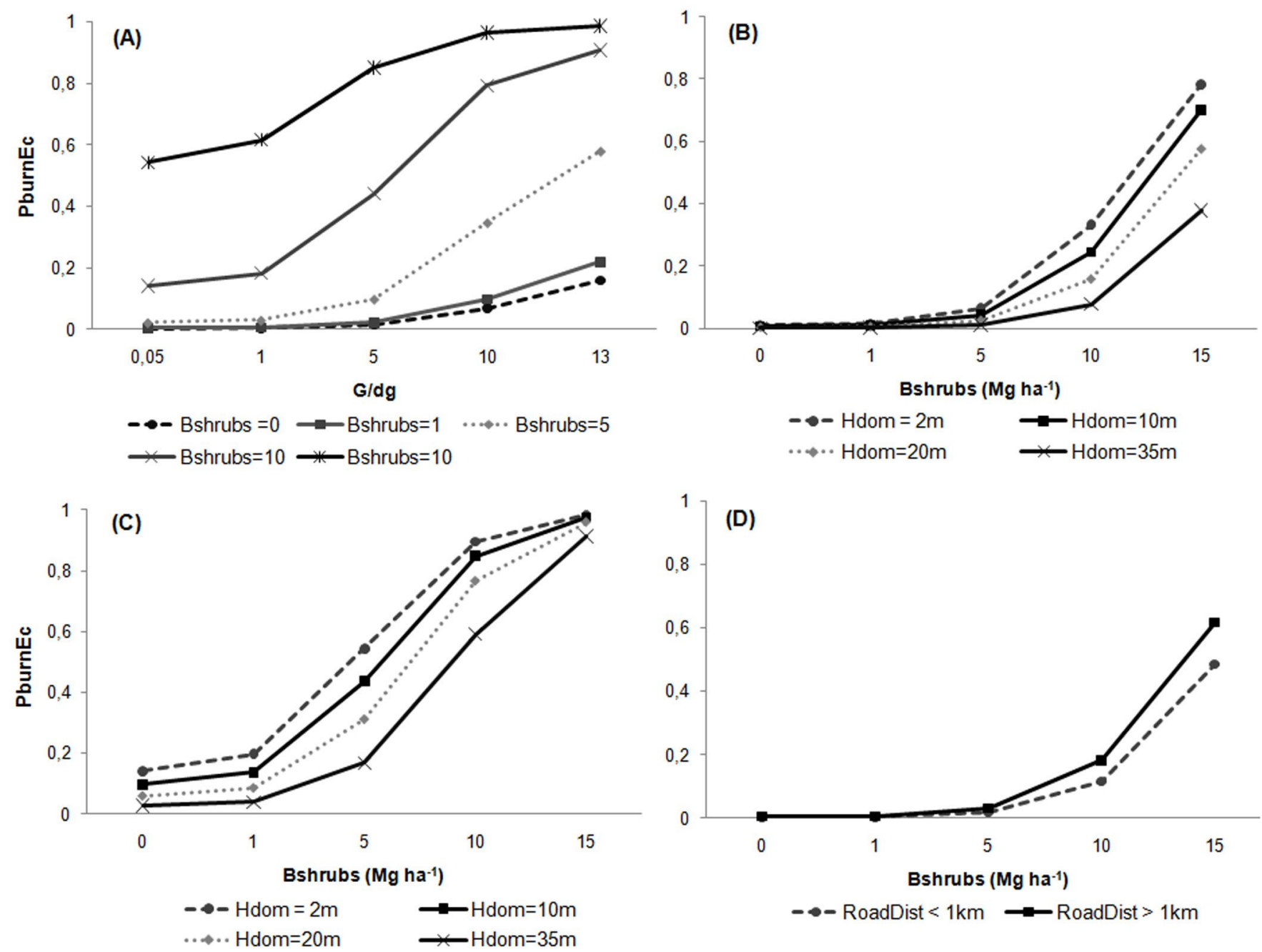

Fig. 4 - Effects of independent variables on the annual wildfire probability ( $P b u r n E c$ ) obtained using eqn. 3 for an example eucalypt stand. (A) Effect of shrubs (Bshrubs, $\mathrm{Mg} \mathrm{ha}^{-1}$ ) and $\mathrm{G} / \mathrm{dg}$ (basal area over quadratic mean diameter); (B) effect of shrub biomass and stand dominant height (with $G / d g=1 \mathrm{~m}^{2} \mathrm{ha}^{-1} \mathrm{~cm}^{-1}$ ); (C) effect of shrub biomass and stand dominant height (with $G / d g=10 \mathrm{~m}^{2} \mathrm{ha}^{-1} \mathrm{~cm}^{-1}$ ); (D) effect of road distance and shrub biomass. Fixed values are the mean values of the whole dataset (Bshrubs $=5 \mathrm{Mg} \mathrm{ha}^{-1}, h d o m=17 \mathrm{~m}$, RoadDist $>1 \mathrm{~km}$ ).

wildfire occurrence probability is higher in stands with prevailing smaller trees (Fig. 3, Fig. 4a). As expected from biological reasons, the model indicates that shrub biomass was the most important variable affecting the probability of wildfire occurrence $(p<0.0001$ - Tab. 4). Further, higher shrub biomass increases the probability of a stand to burn (Fig. 4b e Fig. 4c). On the contrary, the increase of stand dominant height (hdom) decreases this probability. Finally, the model indicates that larger distances to the road

network lead to an increase of the probability of fire occurrence (Fig. 4d).

All parameters estimates in eqn. 3 were found significantly different from zero at the 0.05 level as from the Wald $\chi^{2}$ statistics (Hosmer \& Lemeshow 2000 - Tab. 4). The model was successful in predicting whether fire did occur in $83.5 \%$ of stands (i.e., percentage of concordant pairs). The adequacy of the model was further assessed by the analysis of the ROC curve from the logistic model. The area under the ROC curve $(0.838$

Tab. 4 - Logistic regression parameter estimates and fit statistics for the model predicting the annual wildfire occurrence probability (eqn. 3 ).

\begin{tabular}{lcccrr}
\hline \multicolumn{1}{c}{ Variable } & Parameter & Estimate & \multicolumn{1}{c}{ SE } & Wald $>\boldsymbol{\chi}^{2}$ & \multicolumn{1}{c}{ Pr $>\boldsymbol{\chi}^{\mathbf{2}}$} \\
\hline Intercept & $\beta_{0}$ & -5.4005 & 0.5561 & 94.3193 & $<0.0001$ \\
hdom & $\beta_{1}$ & -0.054 & 0.0232 & 5.4292 & 0.0198 \\
G/dg & $\beta_{2}$ & 0.3166 & 0.1319 & 5.7635 & 0.0164 \\
Bshrubs & $\beta_{3}$ & 0.3959 & 0.0375 & 111.1485 & $<0.0001$ \\
RoadDist $>1 \mathrm{~km}$ & $\beta_{4}$ & 0.5372 & 0.232 & 5.3601 & 0.0206 \\
\hline
\end{tabular}

- Fig. 5) indicates an excellent discrimination (Hosmer \& Lemeshow 2000), thus showing that the selected model performs adequately. Collinearity assessment showed no collinearity among variables included in the model.

The odds ratio further helped the interpretation of results as it provides an intuitive and easily understood assessment of the contribution of an independent variable to the occurrence of an event (Kleinbaum 1996, Hosmer \& Lemeshow 2000). The odds ratio analysis highlighted that the chance of a stand to burn increases 1.486 times if the total biomass of shrubs (Bshrubs) increases one $\mathrm{Mg}$ per ha. Similarly, an eucalypt stand that is more than $1 \mathrm{~km}$ distant from the road network is 1.711 times more prone to burn than a stand that is closer to this network. On the other hand, an increase in 1 meter of eucalypt stand dominant height (hdom) would decrease 0.947 times the fire occurrence 
Tab. 5 - Overall prediction rates for the annual wildfire occurrence probability model (eqn. 3 ). The observed burnt plots percentage was $9.71 \%$. (a): the sensitivity and specificity curves cross (Hosmer \& Lemeshow 2000); (b): average observed survival rate (Monserud \& Sterba 1999); (c) value that maximizes the CCR (Ryan 1997).

\begin{tabular}{cccccc}
\hline $\begin{array}{c}\text { Approach } \\
\text { (cut-point) }\end{array}$ & $\begin{array}{c}\text { CCR } \\
(\mathbf{\%})\end{array}$ & $\begin{array}{c}\text { Sensitivity } \\
(\mathbf{\%})\end{array}$ & $\begin{array}{c}\text { Specificity } \\
(\mathbf{\%})\end{array}$ & $\begin{array}{c}\text { False burnt } \\
(\mathbf{\%})\end{array}$ & $\begin{array}{c}\text { Predicted as } \\
\text { burnt (\%) }\end{array}$ \\
\hline $0.11^{\mathrm{a}}$ & 73.7 & 73.7 & 73.4 & 76.9 & 30.87 \\
$0.28^{\mathrm{b}}$ & 89.9 & 47.7 & 94.5 & 51.9 & 10.52 \\
$0.42^{\mathrm{c}}$ & 93.4 & 38.5 & 99.3 & 14.3 & 6.59 \\
\hline
\end{tabular}

Fig. 5 - ROC curve for eucalypt fire occurrence probability from cross validation data.

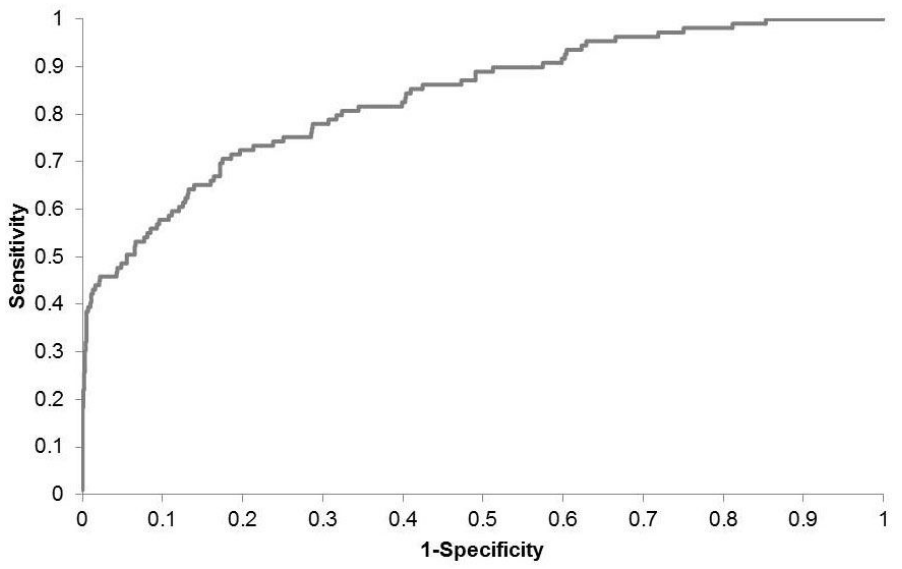

Fig. 6 - Eucalypt coppice stand management scheduling followed by 2 coppiced stands, with an average cutting cycle of 10 years and 1 or 2 shrub cleanings during each cutting cycle.

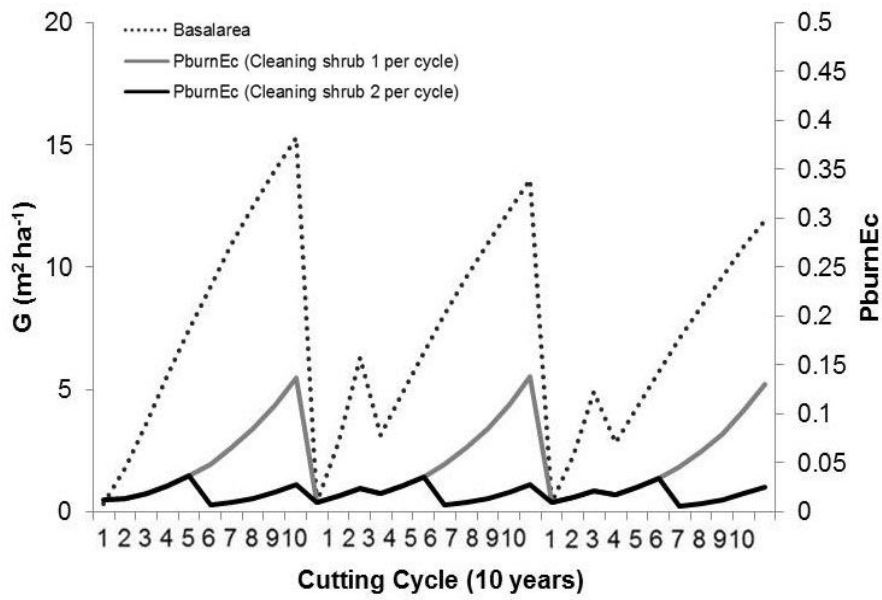

probability, whereas an increase in 5 meters would decrease that probability by 0.763 times.

The most appropriate cut-point for the model was 0.11 as both sensitivity and specificity reach the same proportion is recommended this, enabling a better match between the stands where higher wildfire occurrence probability is predicted and the stands where a wildfire did actually occur. Using this value led to a CCR of $73.7 \%$ (Tab. 5)

Eucalypt coppice stand management scheduling-application example

The model highlighted that coppice cuts and periodic removal of the fuel load do effectively production, conservation and protection objectives. Traditional approaches to fire behavior simulation taking into account the fuel type (e.g., amount, size, and humidity of dead fuels - Finney 2005), the value of environmental variables (e.g., topography and climate), as well as the ignition occurrence, can hardly be used in a typical forest management planning context. They rely on very specific data (e.g., ignition occurrence 20 years from now in the planning horizon, prevailing weather conditions before and during a wildfire occurrence 10 years from now in the planning horizon) that cannot be predicted to support the development of a forest management plan. Fire behavior simulation is a very important tool to enhance policy-making and management planning processes as well as to support strategic zoning and regeneration decisions. Yet forest management planning requires further information to address effectively wildfire risk.

Forest managers need information about the impact of controllable variables (e.g., understory fuel availability, tree species composition, structure and stand density) on the probability of wildfire occurrence (Cumming 2001, Finney 2005, Mercer et al. 2008). This information is influential to design and plan management options aimed to reduce wildfire risk (e.g., González et al. 2006, GarciaGonzalo et al. 2011a, Ferreira et al. 2012). Nevertheless, such information was not available to support eucalypt forest management planning.

Several authors have addressed the effects of fire on eucalypt stands (Curtin 1966, Guinto et al. 1999, Marques et al. 2011b). Fire modeling indicated that wildfire control operations in eucalypt plantations are effective even under extreme weather conditions (Fernandes et al. 2011). Frequent fuel treatments have been demonstrated to reduce fire risk in these ecosystems (Agee et al. 1973, Cheney \& Richmond 1980), thus suggesting the importance of a proactive stand and fuel management strategy (Fernandes 2009). Nevertheless, no quantitative information was available to support the development of an eucalypt forest management plan under wildfire risk.

A logistic modeling approach using simple input variables that are measurable and/or predictable, as well as controllable by forest managers (e.g., shrub fuel load, basal area, dominant height and quadratic mean diameter) was developed to address this shortcoming. Contrarily to former approaches (González et al. 2006), this research took into account vegetation growth dynamics. Our research further confirmed the potential of the logistic model to assess the annual fire occurrence probability in pure and even-aged eucalypt stands in Portugal. In our model, all parameters were significant based on the Wald $\chi^{2}$ statistic test. The area under the 
ROC curve (0.838) indicated excellent discrimination between wildfire occurrence and non-occurrence (Hosmer \& Lemeshow 2000).

According to the proposed model, wildfire risk (i.e., annual burn probability) strongly increases with the shrubs' biomass load. This is in concordance with findings from previous investigations (e.g., Gould et al. 2011, Godinho-Ferreira et al. 2005). Castro et al. (2003) showed that the amount of forest fuels, namely shrubs biomass, may further increase fire severity. Higher amoun of shrubs dry biomass determines higher flammability and lower capability to prevent the advance of fire (Schmidt et al. 2002, Castro et al. 2003). Generally, the fuel load generated by eucalypts increases with stand basal area (Gould et al. 2011). The impact of fuel management on wildfire occurrence has been underlined by the relation between fire risk and shrubs' age (Sah et al. 2006, Gould et al. 2011, Kazanis et al. 2012). The rate of fuel accumulation after a wildfire in a eucalypt forest is relatively high, declining progressively after 5-8 years and stabilizing at a level that depends on the prevailing environmental conditions (Gould et al. 2011). Moreover, the abundance of shrubs contributes to an easier spread of surface fires and facilitate the starting of crown fires because of the vertical fuel continuity (Rothermel \& Philpot 1983, Finney 1999, Cruz et al 2004). From a fire suppression viewpoint, the effectiveness of silvicultural treatments can be gauged by their ability to preven crown fires (Keeley \& Zedler 2009). In a study carried out in Australia by Bradstock $\&$ Williams (2009) crown fires are unlikely in 1 to 5-year old fuels in eucalypt forest even under extreme weather.

Wildfire occurrence in eucalypt stands is also impacted by both tree size indicators (i.e., quadratic mean diameter and stand dominant height) and density indicators (basal area) that may be controlled by management planning. Wildfire occurrence probability increases with higher densities especially in stands with low quadratic mean diameter (i.e., higher $G / d g$ ). This is in concordance with other studies, where similar predicting variables have also been used as an indicator of stand-level competition and have been shown to influence fire risk probability (González et al. 2006). Denser stands comprised of smaller trees are more prone to high-intensity crown fire due to high vertical and horizontal continuity (Van Wagner 1977, Cruz et al. 2004). Wildfire occurrence probability also decreases with stand dominant height (hdom). The literature also provides evidence that such stands are less vulnerable to fire (Fernandes 2009, Fernandes et al. 2010, 2011).

According to the proposed model, eucalypt stands located less than $1 \mathrm{~km}$ from the road network are less prone to burn. This is in concordance with other studies reporting that the proportion of burned areas increases with the distance from roads as a consequence of the lower accessibility by fire fighters (Cardille et al. 2001, Vasconcelos et al. 2001, Badia-Perpinya \& Pallares-Barbera 2006). Other studies in Portugal demonstrated that larger distances impacted the proportion of area burned (Marques et al. 2011a) or that ignitions that resulted in large fires occur further away from roads (Romero-Calcerrada et al. 2010)

In this research, the climate variables used (i.e., number of days of precipitation equal or greater than $1.0 \mathrm{~mm}$ per year and yearly average temperature) express the long-term weather conditions that influence the stand vegetation features (e.g., fuel types). Therefore they characterize the site rather than the weather during a specific fire event. The weather before and/or during a specific wildfire can hardly be predicted within a longterm forest management planning context. According to other studies (e.g., González et al. 2006, Marques et al. 2012), we used climate variables to model wildfire occurrence over long timespans rather than to characterize weather conditions for specific wildfire occurrences.

Our results underlined the importance of fuel treatments to decrease burn probability, and provide indications on which stands are more vulnerable or resistant to fire. Typically, eucalypt stands in Portugal are evenaged plantations with high densities and flammability (Marques et al. 2011b). This research highlighted that emphasis has to be placed on managing the forest structure (i.e., stand density and height) and the fuel loads. This is in concordance with findings by Fernandes et al. (2006) and Fernandes (2009) who showed that stand structure is a major determinant of fire vulnerability.

The modeling approach adopted in this study provide valuable information to integrate risk considerations in both operational and strategic eucalypt forest management planning. It helps quantify the impact of silviculture treatments (e.g., coppice cuts and fuel treatments) on wildfire risk and provides an important tool to define management options aimed to reduce wildfire occurrence and develop effective fires prevention strategies.

The proposed model may be integrated with a growth and yield model (following the approach suggested by Hanewinkel et al. 2010) to predict the probability of a wildfire to occur upon ignition. To this purpose, it may take advantage of wildfire ignition models, such as the ones developed by Vasconcelos et al. (2001) or Catry et al. (2008, 2009), or else consider a stochastic ignition (González et al. 2006). Additionally, the proposed wildfire occurrence probability model can easily be implemented in decision support systems to address wildfire risk in developing management plans either at stand level (e.g., González et al. 2008, PasalodosTato et al. 2010, Garcia-Gonzalo et al. 2011a, Ferreira et al. 2011, 2012) or at landscape level (González-Olabarria \& Pukkala 2011).

The presented model may be applied in different contexts thus contributing to integrate effectively fire risk into forest management planning, and supporting forest managers in the design of prescriptions to manipulate stand endogenous variables that impact the probability of wildfire occurrence. Further research may extend current model with the aim of including landscape structure variables (e.g., neighboring stands biometric variables).

\section{Acknowledgements}

This research was supported by project "Decision support tools for integrating fire and forest management planning" (PTDC/ AGR-CFL/64146/2006) funded by the Portuguese Science Foundation; project FIREENGINE: "Design Flexivel de Sistemas de Gestão de Incêndios Florestais" (MIT/FSE/ 0064/2009); project MOTIVE: "Models for Adaptive Forest Management", funded by $7^{\text {th }}$ EU Framework Programme; and project ForEAdapt, funded by the EU $7^{\text {th }}$ Framework Programme (FP7-PEOPLE-2010-IRSES) under grant agreement no. PIRSES-GA2010-269257. The authors would like to thank the Portuguese Science Foundation for funding the $\mathrm{PhD}$ of Brigite Botequim (SFRH/BD/44830/2008) and Susete Marques (SFRH/BD/62847/2009). The authors wish also to acknowledge the Portuguese Forest Service for providing the perimeters of wildfires and NFI Databases. The authors want to thank Dr. Paulo Fernandes and Dr. Ane Zubizarreta-Gerendiain for the relevant remarks and suggestions and Dr. João Freire for his advice using the statistical software. The authors are also grateful to Susana Barreiro for the use of the software SIMPLOT to model the growth of the inventory plots.

\section{References}

Agee JK, Skinner CN (2005). Basic principles of forest fuel reduction treatments. Forest Ecology and Management 211: 83-96. - doi: 10.1016/j.foreco.2005.01.034

Agee JK, Wakimoto RH, Darley EF, Biswell HH (1973). Eucalyptus fuel dynamics, and fire hazard in the Oakland Hills. California Agriculture, 13-15 September 1973, CA, USA.

Badia-Perpinya A, Pallares-Barbera M (2006). Spatial distribution of ignitions in Mediterranean periurban and rural areas: the case of Catalonia. International Journal of Wildland Fire 15: 187196. - doi: 10.1071/WF04008

Barreiro S, Tomé M (2011). Simplot: Simulating the impacts of fire severity on sustainability of 
eucalyptus forests in Portugal. Ecological Indicators 11: 36 -45. - doi: 10.1016/j.ecolind.2009. 06.015

Botequim B, Borges P, Carreiras J, Oliveira MM, Borges J (2009). Development of a shrub growth model in understory conditions (preliminary model), Technical Report 7, FORCHANGE, Instituto Superior de Agronomia, Lisboa, Portugal. Bradstock RA, Williams RJ (2009). Can Australian fire regimes be managed for carbon benefits? New Phytologist 183:931-934. - doi: 10.1111/j.1469-8137.2009.02958.x

Burnham KP, Anderson DR (2003). Model selection and multi model inference: a practical in formation-theoretic approach. Springer, New York, USA

Bylin CV (1982). Estimating dbh from stump diameter from 15 southern species. USDA Forest Service Research, New Orleans, LA, USA, vol. 286, pp. 1-3.

Cardille JA, Ventura SJ, Turner MG (2001). Environmental and social factors influencing wildfires in the Upper Midwest, USA. Ecological Applications 11:111-127. - doi: 10.1890/10510761(2001)011[0111:EASFIW]2.0.CO;2

Carreiras JMB, Pereira JMC (2006). An inductive fire risk map for Portugal. In: Proceedings of the " $5^{\text {th }}$ International Conference on Forest Fire Research" (DX Viegas ed). Figueira da Foz (Portugal) 27-30 November 2006. Associação para o Desenvolvimento da Aerodin'mica Industrial, ADAI, Coimbra, Portugal. [CD-ROM]

Castro FX, Tudela A, Sebastià MT (2003). Modeling moisture content in shrubs to predict fire risk in Catalonia (Spain). Agricultural and Forest Meteorology 116: 49-59. - doi: 10.1016/S01681923(02)00248-4

Catry FX, Rego FC, Moreira F, Bação F (2008). Characterizing and modelling the spatial patterns of wildfire ignitions in Portugal: fire ignitions and resulting burned area. In: " Modelling, monitoring and management of forest fires" (De La Heras J, Brebbia CA, Viegas D, Leone V eds). WIT Transactions on Ecology and the Environment 199: 213-221. - doi: 10.2495/FIVA080221 Catry FX, Rego FC, Bação F, Moreira F (2009). Modeling and mapping wildfire ignition risk in Portugal. International Journal of Wildland Fire 18: 921-931. - doi: 10.1071/WF07123

Ceccato P, Gobron N, Flasse S, Pinty B, Tarantola S (2002). Designing a spectral index to estimate vegetation water content from remote sensing data - part 1. Theoretic approach. Remote Sensing of Environment 82: 188-197. - doi: 10.1016/S0034-4257(02)00037-8

Cheney NP, Richmond RR (1980). The impact of intensive forest management on fire protection with special regard to plantations of eucalypts. Prepared for the $11^{\text {th }}$ Commonwealth Forestry Conference, Canberra, Australia.

Crecente-Campo F, Marshall P, Rodríguez-Soalleiro R (2009). Modeling non-catastrophic individual-tree mortality for Pinus radiata plantations in northwestern Spain. Forest Ecology and Management 257: 1542-1550. - doi: 10.1016/j. foreco.2009.01.007
Cruz MG, Alexander ME, Wakimoto RH (2004). Modeling the likelihood of crown fire occurrence in conifer forest stands. Forest Science 50 (5): 640-658.

Cumming SG (2001). Forest type and wildfire in the Alberta boreal mixedwood: what do fires burn? Ecological Applications 11: 97-110. - doi: 10.1890/1051-0761(2001)011[0097:FTAWIT]2. $0 . \mathrm{CO} ; 2$

Curtin RA (1966). The effect of fire on tree health and growth. Technical Paper no. 13, New South Wales Forest Commission, Sidney, Australia, pp. 21-35.

DGRF (2006). Estratégia nacional para as Florestas, Direcção-Geral dos Recursos Florestais, Lisboa, Portugal, pp. 189. [In Portuguese]

DGRF (2007). Análise da evolução do comércio externo de produtos florestais. Boletim de Informação. Direcção-Geral dos Recursos Florestais, Lisboa, Portugal, pp. 21. [In Portuguese]

Diéguez-Aranda U, Barrio-Anta M, Castedo-Dorado F, Balboa-Murias M (2003). Estimación del diámetro normal y del volumen del tronco a partir de las dimensiones del tocón para seis especies forestales comerciales de Galicia. Investigación Agraria - Sistemas y Recursos Florestales 12 (2): 131-139. [In Spanish]

Duncker P, Barreiro S, Hengeveld GM, Lind T, Mason WL, Ambrozy S, Spiecker H (2012). Classification of forest management approaches: a new methodological framework and its applicability to European forestry. Ecology and Society 17(4): 51. - doi: 10.5751/ES-05262-170451 Fernandes P (2009). Combining structure data and fuel modeling to classify fire hazard in Portugal. Annals of Forest Science 66: 4-15. - doi: 10.1051 /forest $/ 2009013$

Fernandes P, Rigolot E (2007). The fire ecology and management of maritime pine (Pinus pinaster Ait.). Forest Ecology and Management 241: 1-13. - doi: 10.1016/j.foreco.2007.01.010

Fernandes P, Botelho H, Rego F (2005). A piroecologia do Pinheiro bravo. Silva Lusitana 13 (2): 233-248. [In Portuguese]

Fernandes P, Luz A, Loureiro C (2010). Changes in wildfire severity from maritime pine woodland to contiguous forest types in the mountains of northwestern Portugal. Forest Ecology and Management 260: 883-892. - doi: 10.1016/j.foreco. 2010.06.008

Fernandes P, Luz A, Loureiro C, Godinho-Ferreira P, Loureiro H (2006). Fuel modelling and fire hazard assessment based on data from Portugal National Inventory. In: Proceedings of the "International Conference on Forest Fire Research" (Viegas X ed). ADAI, Figueira da Foz, Portugal. Fernandes $\mathrm{P}$, Loureiro $\mathrm{C}$, Palheiro $\mathrm{P}$, ValeGonçalves HF, Fernandes M, Cruz M (2011). Fuels and fire hazard in Blue Gum (Eucalyptus globulus) stands in Portugal. Boletín del CIDEU 10: 53-61.

Ferreira L, Constantino M, Borges JG (2011). A stochastic approach to optimize Maritime pine (Pinus pinaster Ait.) stand management scheduling under fire risk. An application in Portugal. Annals of Operations Research. [in press].
Ferreira L, Constantino M, Borges J, Garcia-Gonzalo J (2012). A stochastic dynamic programming approach to optimize short-rotation coppice systems management scheduling: an application to eucalypt plantations under wildfire risk in Portugal. Forest Science 58: 353-365. - doi: 10.5849/forsci.10-084

Finney MA (1999). Mechanistic Modelling of landscape fire patterns. In: "Spatial Modelling of Forest Landscape Change: Approaches and Applications" (Mladenoff DJ, Baker WL eds), Cambridge University Press, Cambridge, UK, pp. 186-209.

Finney MA (2005). The challenge of quantitative risk analysis for wildland fire. Forest Ecology and Management 211: 97-108. - doi: 10.1016/j. foreco.2005.02.010

Freire J (2009). Modelação do Crescimento e da Produção de Pinha no Pinheiro Manso. Dissertação de Doutoramento em Engenharia Florestal. Instituto Superior de Agronomia, UTL, Lisboa, Portugal. [in Portuguese]

Garcia-Gonzalo J, Pukkala T, Borges J (2011a). Integrating fire risk in stand management scheduling. An application to Maritime pine stands in Portugal. Annals of Operational Research. - doi: 10.1007/s10479-011-0908-1

Garcia-Gonzalo J, Marques S, Borges JG, Botequim B, Oliveira MM, Tomé J, Tomé M (2011b). A three-step approach to post-fire mortality modelling in maritime pine (Pinus pinaster Ait.) stands for enhanced forest planning in Portugal. Forestry 84 (2): 197-206. - doi: 10.1093/ forestry/cpr006

Garcia-Gonzalo J, Zubizarreta-Gerendiain A, Ricardo A, Marques S, Botequim B, Borges JG, Oliveira MM, Tomé M, Pereira JMC (2012). Modelling wildfire risk in pure and mixed forest stands in Portugal. Allgemeine Forst und Jagdzeitung (AFJZ) - German Journal of Forest Research 183 (11/12): 238-248.

Godinho-Ferreira P, Azevedo A, Rego F (2005). Carta da tipologia florestal de Portugal continental. Silva Lusitana 13: 1-34. [in Portuguese]

González-Olabarria J, Pukkala T (2011). Integrating fire risk considerations in landscape-level forest planning. Forest Ecology and Management 261: 278-287. - doi: 10.1016/j.foreco.2010.10. 017

Gould JS, McCaw W, Cheney NP (2011). Quantifying fine fuel dynamics and structure in dry eucalypt forest (Eucalyptus marginata) in western Australia for fire management. Forest Ecology and Management 262 (3): 531-546. - doi: 10.1016/j.foreco.2011.04.022

González JR, Palahí M, Trasobares A, Pukkala T (2006). A fire probability model for forest stands in Catalonia (north-east Spain). Annals of Forest Science 63: 169-176. - doi: 10.1051/forest:2005 109

González JR, Palahí M, Pukkala T, Trasobares A (2008). Optimising the management of Pinus nigra Arn. stands under endogenous risk of fire in Catalonia. Investigación Agraria - Sistemas y Recursos Forestales 17 (1): 10-17.

Graham RT,Harvey A,Jain TB,Tonn JR (1999). 
The effects of thinning and similar stand treatments on fire behavior in western Forests. General Technical Report PNW-GTR-463, USDA Forest Service, Portland, OR, USA.

Graham R, McCaffrey S, Jain T (2004). Science basis for changing forest structure to modify wildfire behavior and severity. USDA Forest Service, Fort Collins, CO, USA, pp. 43.

Guinto DF, House APN, Xu ZH, Saffigna PG (1999). Impacts of repeated fuel reduction burning on tree growth, mortality and recruitment in mixed species eucalypt forests of southeast Queensland, Australia. Forest Ecology and Management 115: 13-27. - doi: 10.1016/S03781127(98)00434-4

Hanewinkel M, Peltola H, Soares P, GonzálezOlabarria JR (2010). Recent approaches to model the risk of storm and fire to European forests and their integration into simulation and decision support tools. Forest Systems 19: 30-47. [online] URL: http://www.cabdirect.org/abstracts/201130 61405.html

Hosmer DW, Lemeshow S (2000). Applied logistic regression $\left(2^{\text {nd }}\right.$ edn). Probability and Mathematical Statistics, vol. 452, Wiley Series, New York, USA, pp. 307.

ICNF (2013). IFN6 - Áreas dos usos do solo e das espécies florestais de Portugal continental. Resultados preliminares. Instituto da Conservação da Natureza e das Florestas, Lisboa, Portugal, pp. 34. [in Portuguese]

Jactel H, Nicoll BC, Branco M, González-Olbararria JR, Grodzki W, Langstrom B, Moreira F, Netherer S (2009). The influences of forest stand management on biotic and abiotic risks of damage. Annal of Forest Science 66 (701): 1-18. doi: $10.1051 /$ forest $/ 2009054$

Kazanis D, Xanthopoulos G, Arianoutsou M (2012). Understorey fuel load estimation along two post-fire chronosequences of Pinus halepensis Mill. forests in Central Greece. Journal of Forest Research 17: 105-109. - doi: 10.1007/ s10310-011-0250-0

Keeley JE, Zedler P (2009). Large, high-intensity fire events in southern California shrublands: Debunking the fine-grain age patch model. Ecological Applications 19: 69-94. - doi: 10.1890/ 08-0281.1

Kleinbaum DG (1996). Logistic regression: a selflearning text. Statistical Methods in Medical Research 5: 103-104. - doi: 10.1177/096228029 600500108

Kozak A, Kozak R (2003). Does cross validation provide additional information in the evaluation of regression models? Canadian Journal of Forest Research 33 (6): 976-987. - doi: 10.1139/x03022

Marques S, Borges JG, Garcia-Gonzalo J, Moreira F, Carreiras JMB, Oliveira MM, Cantarinha A, Botequim B, Pereira JC (2011a). Characterization of wildfires in Portugal. European Journal of Forest Research 130 (5): 775-784. - doi: 10.1007/s10342-010-0470-4

Marques S, Garcia-Gonzalo J, Borges JG, Botequim B, Oliveira MM, Tomé J, Tomé M (2011b). Developing post-fire Eucalyptus globu- lus stand damage and tree mortality models for enhanced forest planning in Portugal. Silva Fennica 45 (1): 69-83.

Marques S, Garcia-Gonzalo J, Botequim B, Ricardo A, Borges J G, Tomé M, Oliveira MM (2012). Assessing wildfire risk probability in Pinus pinaster Ait. stands in Portugal. Forest Systems 21 (1): 111-120. - doi: 10.5424/fs/211 2211-11374

Mather A, Pereira JMC (2006). Transição florestal e fogo em Portugal. In: "Incêndios florestais em Portugal: caracterização, impactes e prevenção" (Pereira JS, Pereira JMC, Rego F, Silva JMN, Silva TP eds). ISA Press, Lisboa, Portugal, pp. 257-282. [in Portuguese]

McArthur AG (1962). Control burning in eucalypt forests. Leaflet no. 80, Commonwealth of Australia Forest and Timber Bureau, Canberra, ACT, Australia.

McArthur AG (1967). Fire behaviour in eucalypt forests. Leaflet no. 107, Commonwealth of Australia Forest and Timber Bureau, Canberra, ACT, Australia.

McClure JP (1968). Predicting tree dbh from stump measurements in the southeast. Research Note SE-99, USDA Forest Service, USA, pp. 4.

Mercer DE, Haight RG, Prestemon JP (2008). Analyzing trade-offs between fuels management, suppression, and damages from wildfire. Forestry Sciences 79 (4): 247-272. - doi: 10.1007/ 978-1-4020-4370-3 13

Myers RH (1990). Classical and modern regression with applications. PWS-Kent Publishing, Boston, MS, USA, pp. 488.

Monserud R, Sterba H (1999). Modeling individual tree mortality for Austrian tree species. Forest Ecology and Management 113 (2/3): 109123. - doi: 10.1016/S0378-1127(98)00419-8

Moreira F, Rego FC, Ferreira PG (2001). Temporal (1958-1995) pattern of change in a cultural landscape of northwestern Portugal: implications for fire occurrence. Landscape Ecology 16: 555567. - doi: 10.1023/A:1013130528470

Moreira F, Vaz P, Catry FX, Silva JS (2009). Regional variations in wildfire susceptibility of land-cover types in Portugal: implications for landscape management to minimize fire hazard. International Journal of Wildland Fire 18: 563574. - doi: 10.1071/WF07098

Moreno JM (1999). Forest fires: trends and implications in desertification prone areas of Southern Europe. In: "Mediterranean desertification: research results and policy implications" (Balabanis P, Peter D, Ghazi A, Tsogas M eds). DG Research, European Commission, Brussels, Belgium, pp. 115-150.

Nogueira CDS (1990). A floresta Portuguesa. DGF Informação 2: 18-28. [in Portuguese]

Nunes MCS, Vasconcelos MJ, Pereira JMC, Dasgupta N, Alldredge RJ, Rego FC (2005). Land cover type and fire in Portugal: do fires burn land cover selectively? Landscape Ecology 20: 661-673. - doi: 10.1007/s10980-005-0070-8 Omi PN, Martinson EJ (2004). Effectiveness of thinning and prescribed fire in reducing wildfire severity . In: Proceedings of the Sierra Nevada
Science Symposium: "Science for Management and conservation" (Murphy DD, Stine PA ed). General Technical Report PSW-193, USDA Forest Service, Albany, CA, USA, pp. 87-92.

Pausas JP, Llovet J, Rodrigo A, Vallejo R (2008). Are wildfires a disaster in the Mediterranean basin: a review. International Journal of Wildland Fire 17 (6): 713-723. - doi: 10.1071/WF07 151

Pasalodos-Tato M, Pukkala T, Rojo Alboreca R (2010). Optimal management of Pinus pinaster in Galicia (north-western Spain) under endogenous risk of fire. International Journal of Wildland Fire 19 (7): 937-948. - doi: 10.1071/WF08150 Peet GB (1965). A fire danger rating and controlled burning guide for the northern Jarrah $(E$. marginata) forest of western Australia. Bulletin No. 74, Forests Department of Western Australia, Perth, WA, Australia.

Pereira JS, Santos TN (2003). Fire risk and burned area mapping in Portugal. Direcção Geral das Florestas, Lisboa, Portugal.

Pereira JS, Carreiras JMB, Silva JMN, Vasconcelos MJ (2006). Alguns conceitos básicos sobre fogos rurais em Portugal. In: "Incêndios Florestais em Portugal" (Pereira JS, Pereira JMC, Rego FC, Silva JMN, SilvaTP eds). ISAPress, Lisboa, Portugal, pp. 133-161. [in Portuguese]

Pereira JS, Correia AV, Correia AP, Pereira JMC, Oliveira AC, Freitas H, Reis RM, Branco M, Caldeira MC, Cruz CS, Bugalho M, Vasconcelos MJ (2002). Forests and biodiversity. In: "Climate Change in Portugal. Scenarios, Impacts and Adaptation Measures" (Santos FD, Forbes K, Moita R eds). Gradiva, Lisboa, Portugal, pp. 369-413.

Peterson DL, Jonhson MC, Agee JK, Jain TB, Mckenzie D, Reinhard ED (2005). Forest structure and fire hazard in dry forests of the western United States. General Techical Report PNWGTR-628, Pacific Northwest Research Station, USDA Forest Service, Portland, OR, USA, pp. 30.

Rego F (1992). Land use change and wildfires. In: "Responses of forest ecosystems to environmental changes"(Teller A, Mathy P, Jeffers JNR eds). Elsevier Applied Science, London, UK, pp. 367-373.

Romero-Calcerrada R, Barrio-Parra F, Millington JDA, Novillo CJ (2010). Spatial modelling of socioeconomic data to understand patterns of human-caused wildfire ignition risk in the SW of Madrid (central Spain). Ecological Modelling 221: 34-45. - doi: 10.1016/j.ecolmodel.2009.08. 008

Rothermel RC (1983). How to predict the spread and intensity of forest and range fires. General Technical Report INT-143, Intermountain Forest and Range Experiment Station, USDA Forest Service, Ogden, UT, USA.

Rothermel RC, Philpot CW (1983). How to predict the spread and intensity of forest and range fires. GTR-INT-143, USDA Forest Service, Intermountain Forest and Range Experiment Station, Ogden, UT, USA, pp. 161.

Rundel PW (1998). Landscape disturbance in Mediterranean ecosystems: an overview. In: 
"Landscape disturbance and biodiversity in Mediterrean-type ecosystems" (Rundel PW, Monenegro G, Jaksic FM eds). Springer-Verlag, Berlin, Germany, pp. 3-22.

Ryan TP (1997). Modern regression methods. John Wiley and Sons, New York, USA.

Sah JP, Ross MS, Snyder JR, Koptur S, Cooley, HC (2006). Fuel loads, fire regimes, and postfire fuel dynamics in Florida Keys pine forests. International Journal of Wildland Fire 15: 463 478 - doi: 10.1071/WF05100

SAS Institute Inc. (2004). SAS/STAT User's Guide (version 8 edition). SAS Institute Inc., Cary, NC, USA.

Schmidt KM, Menakis JP, Hardy CC, Hann W1J, Bunnell DL (2002). Development of coarse-scale spatial data for wildland fire and fuel management. General Technical Report RMRS-GTR-87, Rocky Mountain Research Station, USDA Forest Service, Fort Collins, CO, USA, pp. 41.
Shapiro JH (1999). Bounds on the area under the ROC curve. Journal of the Optical Society of America A 16: 53-57. - doi: 10.1364/JOSAA.16. 000053

Silva JS, Moreira F, Vaz P, Catry F, Godinho-Ferreira $\mathrm{P}$ (2009). Assessing the relative fire proneness of different forest types in Portugal. Plant Biosystems 173 (3): 597-608. - doi: 10.1080/ 11263500903233250

Soares P, Tomé M (2001). A tree crown ratio prediction equation for eucalypt plantations. Annals of Forest Science 58: 193-202. - doi: 10.1051/ forest:2001118

Tomé M, Oliveira T, Soares P (2006). O modelo GLOBULUS 3.0. Dados e equações. Relatórios Técnico-Científicos do GIMREF, n²/2006, Dep. Engenharia Florestal, Instituto Superior de Agronomia, Universidade Técnica de Lisboa, Lisboa, Portugal. [in Portuguese]

Tomé M, Meyer A, Ramos T, Barreiro S, Faias
SP, Cortiçada A (2007). Relações hipsométricas e equações de di'metro da copa desenvolvidas no 'mbito do tratamento dos dados do Inventário Florestal Nacional 2005-2006, Publicações GIMREF, RT 3/2007, Universidade Técnica de Lisboa, Instituto Superior de Agronomia, Centro de Estudos Florestais, Lisboa, Portugal. [in Portuguese]

Van Wagner CE (1977). Conditions for the start and spread of crown fire. Canadian Journal of Forest Research 7: 23-34. - doi: 10.1139/x77004

Vasconcelos M, Meyer MJ, Silva S, Tomé M, Alvim M, Pereira JMC (2001). Spatial prediction of fire ignition probabilities: comparing logistic regression and neural networks. Photogrammetric Engineering and Remote Sensing 67 (1): 73 81. 